\title{
Communicating Dissent in Judicial Opinions: A Comparative, Genre-Based Analysis
}

\author{
Stanisław Goźdź-Roszkowski ${ }^{1}$ iD
}

Published online: 16 May 2020

(c) The Author(s) 2020

\begin{abstract}
To date, there has been surprisingly little research on separate opinions in legal linguistics literature. Scarce attention has been paid to the linguistic and communicative aspects of how judges frame their disagreements. This paper serves as one of the early attempts to examine the institution of votum separatum, or separate opinion, from a comparative, cross-language perspective using a linguistic methodology. The evidence indicates a clear similarity in terms of how separate opinions are integrated within the respective macrostructures of the US SC opinions and the Constitutional Tribunal judgments. This study demonstrates how judges tend to employ highly formulaic expressions to signal their disagreement despite the absence of clear guidelines to communicate such stances. The analysis of their frequent phraseology demonstrates that declaring votum separatum and providing its justification are two different acts, not only legally but also linguistically, especially in terms of their formulaicity. The Polish and American justifications differ in the degree to which the frequent phraseology reveals peculiarities of judicial argumentation in addition to the presence of strong evaluative concerns.
\end{abstract}

Keywords Judicial discourse $\cdot$ Separate opinion · Phraseology $\cdot$ Legal communication · Genre analysis

\section{Introduction}

Separate opinions, also referred to as votum separatum, ${ }^{1}$ represent one of the most intriguing and least researched types of judicial expression related to the process of making and justifying judicial decisions. On the one hand, they seem to carry little authoritative legal force and, generally, have no precedential value, but on the other,

\footnotetext{
1 In this paper, the terms 'separate opinion' and 'votum separatum' are used interchangeably, with the latter being the preferred form regarding Polish judgments.

Stanisław Goźdź-Roszkowski

stanislaw.gozdz@uni.lodz.pl

1 Department of Specialized Languages and Intercultural Communication, University of Lodz, Pomorska 171/173, 90-236 Lodz, Poland
} 
separate opinions are regarded as significant for a number of reasons, one of which is fostering the transparency of the judicial process since they enable individual judges to voice their disagreement with a majority opinion [e.g., 17, 26]. At the same time, the expression of judicial dissent has provoked considerable controversy. For example, Kirby poses the vexed question of whether judicial dissent represents irrelevant distraction or whether it should be regarded as institutional necessity ensuring the legitimacy of the judicial process. In civil-law systems, the nameless, stylized judgment, and the disallowance of dissent are thought to foster public perception of law as stable and secure. However, as far as constitutional courts are concerned, separate opinions are permitted in most courts with few exceptions [25]. Recent trends appear to favour the right to dissent in virtually all Polish courts [20].

Votum separatum is often said to weaken the institutional impact of the Court because it may cast doubts as to the correctness or fairness (in axiological terms) of a ruling. Its opponents argue that it may question the clarity, finality, and decisiveness of a court's decision. Moreover, the absence of votum separatum evidently encourages judges to search for compromise in their argumentation. Perhaps more importantly, separate opinions are said to affect the legitimacy of a ruling, legally, since they might encourage appeal proceedings and increase the risk of the decision being overturned, as well as socially. The latter point is addressed by Justice Ginsburg [17] in her published lecture on dissenting opinions, where she points out the extra weight carried by the Court's unanimous opinion in Brown v. Board of Education. In this landmark decision of 1954, the U.S. Supreme Court ruled that American state laws establishing racial segregation in public schools were unconstitutional. In that case, all nine Justices signed one opinion making it clear that the Constitution would not tolerate legally-enforced segregation in American schools.

The perception in Poland, until recently, held it was preferable to ensure a unanimous decision. In other words, there was a perceived value in the court speaking with a single voice. Additionally, in Polish jurisprudence, some doubt was expressed as to whether a judge should have the right to voice dissent at all [20]. Other unresolved issues include the scope, the way of communicating and justifying votum separatum. Equally puzzling appears to be the linguistic status of a separate opinion as a generic construct. Could separate opinions be treated as a distinct genre or perhaps they should be treated as part of a judicial opinion or judgment? How conventionalized is the language of judicial dissent? Do judges employ predictable patterns of linguistic expression to signal their stances?

Inevitably, the status, role, and construal of separate opinions tend to vary depending on a given legal system or tradition. While dissent in the common law system is a common feature, in multi-member courts and tribunals, it tends to be dismissed as non-existing or, at least not always revealed in civil law jurisdictions, largely due to the nature of the legal tradition where judges issue a collective judgment cast in stylized, impersonal language. Tiersma [40] notes that because of the power of the judges who write them, some judicial opinions may display substantial freedom in tone and in form. He goes on to provide an example of one judicial opinion composed in verse. Indeed, it is also not entirely uncommon to come across puns, humour and some literary flourishes in judicial writing and metaphors seem particularly rampant. Apparently, judges give themselves even more stylistic latitude in dissenting opinions. The question 
remains whether the freedom of expression taken for granted in the common-law tradition, which prizes the independence of the individual judge to speak in his or her own voice and the transparency of the judicial process, is also the case in the civil law tradition to which Polish legal system belongs.

Grochowski, a legal scholar and judge on the Polish Supreme Court, insists that votum separatum "has come out of the shadows" in Poland [20, p. 138]. It is now openly admitted that a decision was not reached unanimously and the votum separatum with its justification is no longer treated as something to be hidden from the public eye. Still, the manner in which the justification of votum separatum is revealed may vary depending on specific procedural regulations and the ensuing judicial practice. In order to appreciate the momentum of this perceived change in the judicial practice in Poland, it should be stressed that it was as recently as 1988 that major restrictions on votum separatum were lifted. Still, votum separatum could not be revealed freely. This reflected a sharp division in the Polish legal doctrine and judicial practice, with some legal scholars and practitioners opting for full disclosure and the open nature of votum separatum and its justification, while others favoured maintaining (or even increasing) the degree of restriction.

There has been surprisingly little research into separate opinions in the legal linguistics literature. Scarce attention has been paid to the linguistic and communicative aspects of how judges frame their disagreement [see, however, 11]. There are virtually no studies that address this issue from cross-linguistic, genre-based, and intercultural perspectives. The present study is intended as a step towards filling this gap. It offers a closer look at the institution of separate opinion and it examines its functions in view of its diverse audiences. The analysis seeks to determine whether judicial dissent is expressed relying on recurrent lexical combinations and language patterns. It is based on data from the Constitutional Tribunal judgments in Poland and the United States Supreme Court opinions. More specifically, I seek to address the following questions: (1) How are separate opinions positioned within the broad institutional framework of a judicial opinion or judgment?, (2) are there predictable, repeated patterns of expression employed by judges to signal their disagreement?, and (3) how do Polish and American opinions compare in terms of linguistic resources used to signal internal disagreement at the judicial decision-making level?

In what follows, I first discuss the institution of separate opinion with an emphasis on how this concept is understood in the Polish jurisprudence. Sect. 3 focuses on communicative aspects of separate opinions by considering their functions and audiences. Then in Sect. 4 the paper presents the data and the institutional contexts of the United States Supreme Court and Poland's Constitutional Tribunal. Section 5 focuses on methodology and in Sect. 6, I discuss the results of the study. Finally, Sect. 7 brings summary and conclusions.

\section{Separate Opinions: The Concept and Its Nature}

At its simplest, separate opinion, also referred to as votum separatum in the civil law tradition, can be understood as a statement made by a judge which differs from the position taken by the majority. In the Polish jurisprudence, it is described as 
representing a conventional act carried out by an individual judge in accordance with the rules prescribed by the legislator. It is thus a verbal sign of a decision to disagree with the majority opinion. Accordingly, votum separatum constitutes a manifestation of intention that constitutes a specific procedural act, which, somewhat exceptionally is not undertaken by a court or by litigants but by a single judge [37]. Polish legal tradition distinguishes between a votum separatum and its justification emphasizing them as two separate acts in terms of their construction and, as this paper will demonstrate, also in terms of language. This distinction is reflected in most court proceedings since announcing votum separatum invariably precedes the presentation of its justification. The term separate opinion and the corresponding common-law terms dissenting and concurring opinions seem to emphasize the justificatory aspect, while in the Polish civil law tradition, the term votum separatum is reserved for a vote cast by one or more judges against the majority opinion. It would be impossible, of course, to cast a votum separatum without providing reasons. There is a universal requirement to reveal the occurrence of a votum separatum along with its justification.

To some extent, separate opinions could be thus subsumed within the broader concept of legal justification [15], i.e., judges providing reasons for their decisions, orders, rulings, etc. to various audiences: the litigants, other judges, the legal profession, the media and the general public. Yet, separate opinions, or voti separati, are unique because they do not lead to any legal effect that would impact the legal status of any entity. They represent an instance of individual judicial expression which does not involve an exercise of judicial power. Even if Polish law now provides for judicial dissent in virtually all types of court proceedings, it is only regulated in select cases [20]. The legislator focuses on the way in which dissent is formulated, ignoring its justification. As a result, there are no guidelines as to how justification of a votum separatum should be constructed, thereby leaving its linguistic construal to the discretion of the judge involved.

A shared trait of separate opinions, irrespective of jurisdiction, is that they may target any issue arising from the course of proceedings, including the disposition of a case. In practice, they usually concern some aspect of legal reasoning contained in the justification of a decision, such as its validation, interpretation, effect, etc. By and large, a parallel could be drawn between the Polish judicial practice and the common law dichotomy of disagreeing with the ruling (dissenting opinion) and disagreeing with the justification (concurring opinion). ${ }^{2}$ It should be noted that the former carries much more weight while the latter remains generally at the argumentative level. In actual practice, the distinction between the two types becomes blurred. Each and every votum separatum needs justification. Consequently, it engages polemically with both the ruling and its motives. Thus, separate opinions

\footnotetext{
${ }^{2}$ Due to practical constraints, this provides a summary of the differences between the common-law and civil law judicial traditions. For more extensive treatment of separate opinions from the comparative law perspective, see [22, 25]. Also, the discussion here is confined to the 'internal' and 'horizontal disagreement within judges from the same bench and not within a court structure [11].
} 
may assume more complex forms in terms of what judges disagree with, as the following excerpt from a US Supreme Court illustrates (emphasis added):

Kennedy, J., delivered the opinion of the Court, in which Rehnquist, C.J., and Stevens, O'Connor, and Breyer joined, and in which Scalia and Thomas, JJ., joined as to Parts I, II, III, and IV. Stevens, J. filed a concurring opinion. Thomas, J., filed an opinion concurring in part and dissenting in part, in which Scalia, J., joined. Ginsburg, J. filed a dissenting opinion, in which Souter, J. joined [12]

In the example above, the majority opinion is in fact a plurality opinion, i.e., an opinion agreed upon by most judges but for different reasons (due to the occurrence of concurring opinion), while the dissenting opinion disagrees with the decision reached. Additionally, a judge may express partial disagreement with both the decision and its justification (concurring in part and dissenting in part). Unlike in the Polish Constitutional Court, US Supreme Court judges may signal that they agree with their colleague's separate opinion.

As discussed in Sect. 6, the Constitutional Tribunal's separate opinions also enable judges to signal with utmost accuracy the extent of their disagreement with the majority opinion. Interestingly, in case of more than one voti separati, individual opinions do not relate to one another. As mentioned above, the Polish law does not specify how votum separatum should be justified. However, it requires the judge to determine which aspects of the ruling or its justification they disagree with. For example, article $114 \S 1$ of the Polish Code of Criminal Procedure provides that a judge in a criminal case must "specify the extent and the direction in which he or she challenges a ruling., 3

\section{Separate Opinions: Its Audiences and Functions}

The importance of communicative aspects involved in drafting separate opinions are best seen in terms of their recipients. Needless to say, there is a range of audiences interested in separate opinions. Just as in the case of a ruling, providing motives for a judicial dissent increases its social legitimacy. Given the current model of a full and unlimited access to all judicial opinions, ${ }^{4}$ the legitimacy of separate opinions is capable of reaching diverse groups of recipients. Seen from a communicative perspective, the justification of a votum separatum requires that it is based on comprehensive and multi-faceted argumentation available for a wide range of interested parties. This is a key communicative factor as justification is constructed for their benefit and their informational needs are taken into account and translated into pragmatically effective argumentation.

Grochowski [20, p. 152] provides an interesting distinction between two types of audiences: primary addressees (those who are formally intended to read an

\footnotetext{
3 All quotes from the Polish legislation are the author's translation.

${ }^{4}$ Both US and Polish opinions are now freely available in on-line databases.
} 
opinion) and recipients (the de facto readers of an opinion). The justification of a votum separatum is, first and foremost, directed at other judges from the bench, who may already be familiar with its argumentation after deliberations prior to the announcement of a court decision. Other addressees include parties to the case (litigants) who might be interested in the justification of a separate opinion, especially in case a court decision is going to be appealed. The recipients range from appeals court judges (if applicable), other judges from lower courts who might hear similar cases, legal academics, media commentators in case of a much hyped case, as well as members of the general public. While dissenting judges should be expected to focus on the primary addressees, it remains to be seen to what extent they are aware and take into account the expectations and needs of other, less immediate audiences. This aspect seems particularly relevant in the Polish judicial system where making legal justifications publicly available is a relatively recent practice.

Set against such communicative background, separate opinions serve a number of important functions. First and foremost, they provide reasons for expressing disagreement with a majority decision legitimizing the decision. Their function is thus to persuade the reader that the dissent is justified. In this respect, separate opinions resemble other types of opinions in that they all seek social legitimacy stemming from the transparency of the judicial decision-making process and, consequently, increases the credibility of courts in the eyes of the litigants and the general public. An alternative view espoused in a separate opinion could encourage an appeal (in lower courts). Legal scholars have long recognized that the legitimacy of judicial institutions - and courts in particular-proves central to the exercise of their authority, decisional outcomes, and compliance with their decisions [36].

Other functions of a votum separatum may vary depending on the addressees or recipients. In general, justifications of separate opinions contribute to the development of law [36] because they provide alternative ways of interpreting legal provisions, which might become a useful point of reference in other cases heard by the court or for other courts, the legal doctrine and legislation. Put differently, legal reasoning in justifications could, in the long run, spark a change in the way a specific issue is perceived in mainstream legal opinion. ${ }^{5}$ The same point is echoed in Chief Justice Hughes's famous statement made to describe the external impact of dissenting opinions:

A dissent in a Court of last resort is an appeal ... to the intelligence of a future day, when a later decision may possibly correct the error into which the dissenting judge believes the court to have been betrayed. [10, p. 1].

5 See also Vitale [43] for an in-depth assessment of the value of dissent in constitutional adjudication. . 


\section{Data and the Institutional Contexts of US Supreme Court Opinions and Poland's Constitutional Tribunal Judgments}

The analyses carried out in this study are based on two datasets. First, 45 separate opinions totalling 121,866 words were sampled from the Poland's Constitutional Tribunal's official website [34]. This is a database which enables the search all the judgments given by the court since 1997, according to multiple criteria, such as time of publication, type of case, case number, type of judicial panel, etc. The other dataset includes 51 separate opinions from the US Supreme Court (300, 935 words) from free law collections available at the Legal Information Institute [30]. The texts for the present analysis were selected to ensure that the opinions were written by different judges to guard against idiosyncratic uses of language. In addition, they span the period between 1997 and 2017 in order to provide a fairly broad and representative picture of discursive practices occurring in voti separati and their justifications. The quantitative analyses were carried out using a popular Corpus Tool AntConc [1].

Despite the obvious differences between the Common Law and the Continental Civil Law, the Supreme Court in the United States and the Constitutional Tribunal in Poland share some similarities with respect to their composition, competences and functions, as both are the highest courts in their respective jurisdictions. In addition, the courts compared exercise the power of judicial review. ${ }^{6}$ The US Supreme Court combines the competence of the highest appellate court and the constitutional court while, the Constitutional Tribunal hears cases regarding their compliance with the Polish constitution. The former consists of the Chief Justice and eight Associate Justices who are nominated by the president and confirmed by the Senate. Its primary task is to exercise appellate jurisdiction and to serve as the final arbiter in the construction of the Constitution of the United States by providing a uniform interpretation of the law. Appellants must file a petition for writ of certiorari, i.e., they ask the Court to hear their appeal. The certiorari can be either granted or denied. If it is granted, the Court will deliver one of the following opinions: per curiam opinion (unanimous), majority (opinion shared by the majority), plurality (final outcome agreed to by majority but for differing reasons). Individual judges (referred to as justices) can also write their separate opinions, which are either concurring (agreeing with the majority decision for different reasons) or dissenting opinion (disagreeing with the majority). It is not possible to appeal from a S.C. decision. The decisions are binding in all jurisdictions in the United States, but the Supreme Court may overrule its own decisions. ${ }^{7}$

Poland's court system is a complex four-level hierarchy with the regional, district, appellate and highest court. The Constitutional Tribunal (Pol. Trybunat Konstytucyjny) stands apart from this hierarchy resolving disputes related to the constitutionality of actions undertaken by public institutions and its main task is to ensure

\footnotetext{
6 See, however, [24] for an in-depth discussion of differences that distinguish constitutional courts from common law supreme courts and are relevant to studying the practice of dissenting opinions. .

7 See Lee et al. [29] and the US Supreme Court website [42].
} 
the compliance of statutory law with the Constitution of the Republic of Poland. The Constitutional Tribunal was created in 1982 but it started adjudicating on 1 January 1986. The inspiration for creating a separate constitutional court originated with the Solidarity movement and the opposition to the then communist government. The Constitution of 2 April 1997 recognizes four areas of the Constitutional Tribunal's jurisdiction:

1. Reviewing norms (both abstract and specific; a posteriori and a priori-a particular procedure for reviewing the norms is adjudicating on constitutional complaints;

2. Settling disputes over authority between the central constitutional organs of State;

3. Determining whether purposes or activities of political parties are in conformity with the Constitution;

4. Determining whether or not there exists an impediment to the exercise of the office by the President of the Republic.

The Polish system of judicial review rests on three basic procedures: abstract review, legal questions (referred by ordinary or administrative judges deciding individual cases) and constitutional complaints (that are lodged with the Tribunal once appellate procedures have been exhausted) [16]. The other superior courts in Poland are the Supreme Court (Pol. Sad Najwyższy) and the High Administrative Court (Pol. Naczelny Sad Administracyjny), each exercising independent jurisdiction within its area of competence. The Constitution determines, generally, the powers of the superior courts. The Constitution clearly provides that the Constitutional Tribunal is vested with the competence to review ordinary statutes and other legal regulations and to annul them in case of unconstitutionality or nonconformity with the international instruments to which Poland is a party. Such decisions of the Tribunal have an erga omnes effect and are final and universally binding, that is, also binding on all other courts, the Supreme Court included.

In sum, for all their differences, the Supreme Court of the United States and the Polish Constitutional Tribunal share the fundamental competence of resolving cases regarding the constitutionality of legal acts. In so doing, judges are required to provide a rationale for their decisions. This requirement similarly applies to separate opinions.

\section{Methodology}

This study rests on the premise that judicial opinions may be investigated as specific generic products created in the process of actual professional practices. In more recent versions of genre analysis, genre has been redefined as a "configuration of text-internal as well as text-external resources, highlighting two kinds of relationships involving text and context" [7, p. 4]. On the one hand, genres can be treated as "recognizable communicative events" [6, p. 23] marked by communicative and professional goals shared by members of a professional community using them on a 
regular basis in their professional practice, but on the other, genres are highly structured and conventionalized constructs. One of the major questions that this study begins to address concerns constraints on allowable contributions. In other words, how much discretion judges have in formulating their dissent and in justifying it. This issue is explored in two ways. First, the entire judicial instruments (i.e., judicial opinions and judgments) are examined by means of a close reading in order to ascertain how justifications fit within the framework of an entire instrument. This qualitative stage involves scrutinizing the texts of the separate opinions with a view to identifying language resources employed to express dissent or concurrence. Second, the two datasets were analysed in order to examine key instances of formulaicity in context. To that end, frequent expressions were identified based on the concept of lexical bundles. This type of lexical recurrence has been extensively used to study legal discourse from various perspectives [e.g., 9, 18]. Lexical bundles can be defined succinctly as "multi-word sequences that occurred most frequently in particular genres, regardless of whether or not they constituted idioms or structurally complete units" [13, p. 230].

Methodologically, the analysis was carried out as follows. The linguistic software package AntConc was used to generate a list of n-grams or clusters, i.e., multi-word sequences. Given the preliminary and exploratory nature of this study, a number of constraints were adopted: only the ten most frequent lexical bundles were considered with their size varying between 3 and 5 words per bundle, each sequence needed to have a minimum frequency of ten and a distribution of a minimum of ten different texts to guard against the stylistic idiosyncracies of individual judges. The same criteria were applied in both the US and Polish datasets. The bundles were then examined in their co-texts using the Concordance function of the software.

\section{The Structures of Separate Opinion (Votum Separatum) Before the Supreme Court of the United States and the Polish Constitutional Tribunal}

In terms of textual space, legal justification is located in the opinion part of the courts' decisions. Opinions delivered by the Supreme Court of the United States (SC) generally consist of four major parts [14]: (1) headnote-which includes the names of the parties, identification of parties (their role in the proceedings, i.e., petitioner, respondent), an identification of the court in which the recorded case was heard, and the date of the opinion, (2) procedural history-this section contains a brief description of how the lower-instance courts dealt with the case. It usually includes the basis for review, i.e., the reasons why the Supreme Court heard the case; (3) holding - this section, invariably signalled by the use of the word held, provides the decision (ruling) reached by the Supreme Court in a particular case ended with a disposition of the case (e.g., affirmed, vacated and remanded). The holding is usually followed by a summary of the court's argument; (4) opinion - unlike the previous sections which are usually prepared by a court clerk, this final part is authored by individual judges and it includes judicial argumentation provided in order to justify the decision reached by the court. It 
explains the law as applied to the case and provides the reason on the basis of which the decision is made. Separate (dissenting and concurring opinions) are provided after a court's (majority or plurality) opinion. A list of all opinions with the names of the judges is given before the opinion of the court as in the following example from the Masterpiece Cakeshop, Ltd., et al., Petitioners v. Colorado Civil Rights Commission, et al. Apart from signalling the type of opinion offered, as well as its scope (e.g., concurring in part), it is possible to indicate that a given opinion attracted the support of another judge (e.g., in which GORSUCH joined).

KENNEDY, J., delivered the opinion of the Court, in which ROBERTS, C. J., and BREYER, ALITO, KAGAN, and GORSUCH, JJ., joined. KAGAN, J., filed a concurring opinion, in which BREYER, J., joined. GORSUCH, J., filed a concurring opinion, in which ALITO, J., joined. THOMAS, J., filed an opinion concurring in part and concurring in the judgment, in which GORSUCH, J., joined. GINSBURG, J., filed a dissenting opinion, in which SOTOMAYOR, J., joined [32]

The structure of a Constitutional Tribunal judgment is to some extent similar. It also starts with a headnote (Pol. komparycja), which contains the date, case number, type of court decision (judgment, order) and the composition of a bench (adjudication panel) since its size may vary depending on the type of proceedings. The next part, (Pol. tenor), corresponds to holding in S.C. opinions. It contains a disposition of the case, i.e., what the court adjudicates and rules (Pol. orzeka $i$ postanawia). This is followed by the justification of the court's decision. Unlike their US counterparts, justifications given by the Constitutional Tribunal have a fixed structure which consists of three parts. First, there is a historical part which refers to all the documents pertinent to a given case. In this part, the contents of an application (petition) and its basis are described. This part also provides the details of a charge and the challenged regulation as well as the positions taken by each of the interactants (parties to the proceedings) along with their most important arguments. The second part called 'at the trial' (Pol. na rozprawie) reports material circumstances which occurred between the first court hearing and the verdict. The third part is the proper justification where legal argumentation is provided. This part usually focuses on legal admissibility of a petition (Pol. ocena dopuszczalności wniosku), a specific constitutional issue, reviewing standards (Pol. wzorzec kontroli) and relevance of the grounds for an application (Pol. ocena zasadności wniosku). Its actual composition may vary depending on the merits of a give case [28]. Finally, separate opinions are provided. Table 1 summarizes the two structures demonstrating the basic similarity between the US S.C. opinion and the Constitutional Tribunal's judgment.

It should be pointed out that the structures described in this section are based on models adopted and prescribed by the two judicial institutions. In other words, they provide an institutional framework in which the separated opinions are embedded. As can be seen, such standardization is extended to the textual organization of the Polish votum separatum, which tends to contain the tripartite division shown above. It should be noted that this type of structure does not result from the rhetorical 
Table 1 The structures of the US S.C. opinion and the Constitutional Tribunal's judgment

\begin{tabular}{ll}
\hline Headnote & Headnote (komparycja) \\
\hline Procedural history & \\
Holding & Holding (tenor) \\
Opinion of the court & Justification of the judgment \\
& Historical part \\
& "At the trial" \\
& Legal justification \\
Concurring/dissenting opinions & Separate opinion(s) (voti separati) \\
\hline
\end{tabular}

GINSBURG, J., dissenting

SUPREME COURT OF THE UNITED STATES

No. $16-111$

MASTERPIECE CAKESHOP, LTD., ET AL., PETITIONERS

v. COLORADO CIVIL RIGHTS COMMISSION, ET AL.

ON WRIT OF CERTIORARI TO THE COURT OF APPEALS OF COLORADO

[June 4, 2018]

JUSTICE GINSBURG, with whom JUSTICE SOTOMAYOR joins, dissenting [32].

Fig. 1 An example of signalling a dissenting opinion before the US SC

moves analysis [e.g., 8, 39] where text segments ate identified on the basis of their communicative purpose. ${ }^{8}$

\section{Formulaic Patterns in the Expression of Judicial Dissent}

We now turn to investigate how judges formulate their dissent in terms of actual linguistic resources used. This section answers the question whether there are any patterns which judges routinely employ or whether such expressions tend to be highly idiosyncratic reflecting the judge's individual style.

The analysis shows that both Polish and US separate opinions signal their scope, i.e., whether they address the ruling or its justification. By way of example, below is the opening part of a dissenting opinion given in the Masterpiece Cakeshop, Ltd., et al., Petitioners v. Colorado Civil Rights Commission, et al. It communicates clearly the judge's disagreement with the court decision. Structurally, it is a separate judicial instrument providing the case number, the date on which the opinion was

\footnotetext{
8 This type of analysis can be found in Goźdź-Roszkowski [19] who examines rhetorical moves in the justifications of the Polish Constitutional Tribunal judgments.
} 
given as well as the parties to the case. Unlike its Polish counterpart, it also mentions a judge who supported the opinion (Justice Ginsburg, with whom Justice Sotomayor joins, dissenting) (Fig. 1).

In a similar vein, a Polish separate opinion indicates the extent of dissent in its title:

(1) Justice Stanislaw Rymar's separate opinion regarding the ruling of the Constitutional Tribunal [46].

[Pol. Zdanie odrębne sędziego TK Stanisława Rymara do wyroku Trybunału Konstytucyjnego]

Polish opinions are even more emphatic in indicating the type of separate opinion. The opening sentence usually reiterates a judge's intention to disagree with a court's decision. It manifests its votum separatum:

(2) Subject to Art. 106 Section 3 of the Act on the organization and procedure before the Constitutional Tribunal (...), I enter my dissent against the ruling of the Constitutional Tribunal of December 19th 2012, case no. K 34/16 (emphasis added) [44].

This sentence is highly formulaic as it is invariably preceded by a reference to the legal act on the basis of which a votum separatum is declared. The Polish original expression zgłaszam zdanie odrębne do (Eng. lit. I enter (my) dissent against) belongs to the ten most frequent four-word bundles identified in the corpus of the Polish judgments (see Table 2). By the same token, it can be used to signal dissent regarding the justification of a court ruling:

(3) I enter my dissent against the justification of the ruling given on 28th of June 2016, case number SK 31/14 [49].

[PL zgłaszam zdanie odrębne do uzasadnienia wyroku z 28 czerwca 2016 r. o sygn. SK 31/14].

In the context of the US S.C. opinions, judges write a concurring opinion to signal their disagreement with the justification of a majority decision:

(4) Justice Thomas, with whom Justice Breyer joins, concurring in the judgment $[5]$.

Characteristically, judges tend to delimit the exact extent of their dissent specifying which part of a judgment they disagree with. This is usually balanced by indicating the areas of agreement:

(5) I agree with Justice Stevens that the mineral reservation provision in the Pittman Underground Water Act of 1919 (Pittman Act or Act) cannot be meaningfully distinguished from the analogous provision in the Stock-Raising Homestead 
Table 2 The ten most frequent 4-5 lexical bundles in the Constitutional Tribunal's separate opinions

\begin{tabular}{|c|c|c|}
\hline Bundle & Frequency (raw) & $\begin{array}{l}\text { Frequency (per } \\
\text { million words) }\end{array}$ \\
\hline $\begin{array}{l}\text { wyrok trybunatu konstytucyjnego } z \\
\text { [Eng. judgment of the Constitutional Tribunal dated] }\end{array}$ & 68 & 445.31 \\
\hline $\begin{array}{l}\text { w zwiazku zart. } \\
\text { [Eng. with regard to Article] }\end{array}$ & 67 & 438.77 \\
\hline $\begin{array}{l}\text { wolność sumienia } i \text { wyznania } \\
\text { [Eng. freedom of conscience and religion] }\end{array}$ & 54 & 353.63 \\
\hline $\begin{array}{l}\text { osoba petniqca funkcje publiczna } \\
\text { [Eng. person who holds public office] }\end{array}$ & 51 & 333.99 \\
\hline $\begin{array}{l}\text { do wyroku trybunatu konstytucyjnego } \\
\text { [Eng. regarding the Constitutional Tribunal judgment] }\end{array}$ & 51 & 333.99 \\
\hline $\begin{array}{l}\text { być niezgodnym z art. } \\
\text { [Eng. does not comply with art.] }\end{array}$ & 49 & 320.89 \\
\hline $\begin{array}{l}\text { w sprawie o sygn. } \\
\text { (Eng. in the case no.) }\end{array}$ & 48 & 314.34 \\
\hline $\begin{array}{l}\text { ustawa } z \text { dnia pierwszego } \\
\text { [Eng. Act of } 1 \text { st] }\end{array}$ & 36 & 235.75 \\
\hline $\begin{array}{l}\text { zgtaszać zdanie odrębne do } \\
\text { [Eng.enter a separate opinion regarding] }\end{array}$ & 33 & 216.11 \\
\hline o którym mowa $w$ [Eng. which [is] mentioned in] & 33 & 216.11 \\
\hline
\end{tabular}

Act of 1916 (SRHA). (...) I disagree, however, with the Court's conclusion in Western Nuclear that sand and gravel are "minerals" under the SRHA merely because, hypothetically, at the time of the passage of the SRHA, they could have been used for commercial purposes, 462 U.S., at 55 (emphasis added) [5].

In the case of Polish justifications, the distinction between dissenting and concurring opinions may become blurred when judges voice their disagreement with both the ruling and its justification, as shown in the example below:

(6) I do not agree with the decision and its justification [46].

[PL Nie zgadzam się z sentencja oraz uzasadnieniem wyroku]. (emphasis added).

Just as in the case of a US S.C. concurring opinion provided above, Polish justifications tend to describe very precisely the object of dissent:

(7) I enter my dissent against points 7 and 8 part I of the Constitutional Tribunal ruling [45].

[PL Zgłaszam zdanie odrębne do punktu 7 i 8 czesści I sentencji wyroku Trybunału Konstytucyjnego]. 
It is also discursive practice in Polish separate opinions that judges very often start by indicating areas of agreement with a court decision before they express their dissent, as shown in Example 8.

(8) I support the Tribunal's position on the non-compliance of the challenged provisions with the prohibition of excessive intervention subject to Art. 2 of the Constitution. I do not share the reasoning both with regard to (...) [49].

[PL Popieram stanowisko Trybunału o niezgodności zaskarżonych przepisów z zakazem nadmiernej ingerencji wynikającym z art. 2 Konstytucji. Nie podzielam jednak rozumowania zarówno co do (...)].

One characteristic feature of Polish separate opinions, not often found in the US opinions, is that they tend to justify the very act of expressing dissent. This may assume various linguistic forms as the following examples amply illustrate:

(9) I justify my dissent as follows... [48].

[PL Zdanie odrębne uzasadniam następująco]

(10) The obligation to enter the dissent is motivated as follows (...) [47].

[PL Obowiazek zgłoszenia zdania odrębnego motywuję następujaco]

(11) For these reasons I decided to enter my dissent [48].

[Z tych przyczyn zdecydowałem się na zgłoszenie zdania odrębnego.]

(12) For the reasons provided above, I felt obliged to enter my dissent [47].

[Z podanych wyżej względów czułem się zobligowany do zgłoszenia zdania odrębnego do wyroku Trybunału Konstytucyjnego.]

(13) Given all the above-mentioned arguments, I considered it necessary to enter my dissent [48].

[Majac na uwadze wszystkie powyższe argumenty, złożenie zdania odrębnego $w$ niniejszej sprawie uznatem za konieczne.]

In US separate opinions, there are few instances of such use:

(14) For the foregoing reasons, I join in the Court's opinion [38].

Such statements, as provided in Examples 9-13 are placed either at the beginning or at the end of a separate opinion. Interestingly, they usually signal an element of obligation, implying that a dissenting judge had no choice but to express their disagreement. No such prevalent discursive practice has been found in US separate opinions. This difference could be attributed to the still relatively 
Table 3 The ten most frequent 4-5 lexical bundles in US Supreme Court separate opinions

\begin{tabular}{lcl}
\hline Bundle & Frequency (raw) & $\begin{array}{l}\text { Frequency (per } \\
\text { million words) }\end{array}$ \\
\hline The court of appeals & 155 & 515.06 \\
Concurring in judgment & 98 & 326.6 \\
The fact that & 81 & 269.1 \\
The right to & 80 & 265.8 \\
Dissenting in part & 68 & 225.9 \\
The purpose of & 60 & 199.3 \\
As the court & 59 & 196.0 \\
At the time of & 59 & 196.0 \\
The text of & 52 & 172.7 \\
The basis of & 48 & 159.5 \\
The meaning of & 46 & 152.8 \\
Even if the & 44 & 146.2 \\
\hline
\end{tabular}

weak status of separate opinions in the Polish judicial practice, where judges may feel somewhat compelled to explain their motives for disagreeing with their colleagues.

The examples provided above point to the presence of specific formulaic expressions judges use to signal their dissent with either a ruling or its justification. It remains to be seen whether the same similar degree of formulaicity is found in the justifications themselves. In order to find out more about frequent formulaic patterns in separate opinions, and especially the justifications we turn to consider the most frequent lexical bundles identified in US and Polish datasets.

Tables 2 and 3 list the ten most frequent bundles in the Polish and the US separate opinions, respectively. The scrutiny of the expressions in Polish reveals the occurrence of zgłaszam zdanie odrębne do [Eng. lit. I enter my votum separatum regarding] as extremely frequent. It corresponds functionally to the English phrase dissenting in part, which, in addition, also signals the restricted scope of the judicial disagreement. Interestingly, no other expression directly related to declaring votum separatum has been found in either dataset to be at a corresponding level of frequency. This means that dissent tends to be expressed by means of diverse language forms where their individual linguistic realizations may be relatively infrequent. This is well illustrated by examples 9-13 above, where the linguistically varied forms all share the discourse function of justifying the declaration of votum separatum but they all represent essentially different linguistic realizations (e.g., I justify my dissent as follows, the obligation to enter the dissent is motivated as follows).

Other phraseology listed in Table 2 centres around legal instruments (judgment of the Constitutional Tribunal, the act of 1 st and regarding the Constitutional Tribunal judgment) and expressions marking textual deictics: with regard to art, in the case no., which [is] mentioned in. Two bundles represent terminological phrases: freedom of conscience and religion and person who holds public office) and they reflect the subject matter of specific cases. Given that they are found in at least ten different opinions, their occurrence shows strong axiological concerns 
(freedom of conscience and religion) and the presence of issues related to the accountability of public officials (person who holds public office).

Similar usage patterns in American justifications were documented for bundles referring to the type of a separate opinion. Two expressions concurring in judgment and dissenting in part are oftentimes simply parts of a long formula routinely employed to signal the type of separate opinions and its scope:

(15) Kennedy, J. concurring in judgment and dissenting in part [38].

The major difference between the US and Polish justifications is that the phraseological patterns of the most frequent lexical bundles in American texts are capable of bringing insights into argumentation contained in separate opinions. In this respect, bundles seem to reflect a pattern, identified often in legal texts [e.g., 33], through which they are used to navigate or signpost the reader towards specific elements in the reasoning of judges. The most frequent bundle (the court of appeals) is a reference to the court of appeals and is used to present and evaluate its argumentation in light of counter-arguments made by/within a majority opinion. What follows tends to be an overt evaluation made by the dissenting judge (emphasis added):

(16) The Court lists five reasons why the Court of Appeals abused its discretion. None of these reasons, whether taken separately or considered together, stands up to examination [35].

(17) For this reason, the Court of Appeals was correct to focus on COPA's incorporation of varying community standards and it may have been correct as well to conclude that in practical effort COPA imposes the most puritanical community standard on the entire country [23].

In the examples provided below, the bundles identify important elements of judicial argumentation by focusing on purpose, text and meaning.

(18) Nor does the context indicate otherwise, because Congress clearly authorized the Commissioner to assign retirees to other successors, and extending liability to this category of successors is consistent with the purpose of the Act [4].

(19) This reasoning is dependent upon a particular understanding of the purpose of civil marriage [32].

These examples show how referring to the purpose or the text of a statutory instrument can be used to rebut an argument made in a court's opinion. In Example 20, the dissenting judge points towards the lack of a textual basis for a conclusion reached by the Court. This is shown as a direct reason for declaring dissent.

(20) Because the Court's conclusion is supported neither by the text of the Bankruptcy Code not by any of the agreements executed by the parties, I respectfully dissent [2]. 
As in Examples 16 and 17 above, the dissent continues with an overtly negative evaluation of the Court's argument (emphasis added):

(21) The Court begins its description of this case with the observation that "the settlement agreement does not resolve the issue of fraud, but provides that B will pay A a fixed sum." Based on that erroneous premise, the Court goes on to find that there is "no significant difference between Brown (...) and this case" [2].

There is a clear co-occurrence (around 30\% of the cases) between the bundle the text of and lexical items signalling negation: nothing, neither, not, no. Another example provided below with nothing in subject position adds the extra layer of emphasis in the argument made by a dissenting judge:

(22) Nothing in the text of Article 36(b) supports the Court's sweeping conclusion that it represents an unprecedented congressional effort to change the nature of military commissions from common-law war courts to tribunal that must presumptively function like courts-martial [21].

The expression the meaning of brings to light the central importance of dialectal rules for determining meaning in law and crucial role of definitions in judicial decision-making process [31]. Interestingly, the meaning of tends to co-occur with language items related to doubt or deficit in understanding. Example 23 is yet another instance of judicial discourse which focuses on the negative evaluation of argumentation contained in a majority opinion.

(23) Any lingering doubts about the meaning of the phrase were certainly dispelled by our discussion of the issue in (...) [3].

(24) For, although the Court does not say so explicitly, it apparently assumes that the Senators were either dissembling or unable to understand the meaning of the bill that they were sponsoring. Neither assumption is tenable [4].

The discourse function of the most frequent lexical bundles in US justifications appears to be twofold: providing insight into the peculiarities of the Court's argumentation and identifying language used to evaluate it. The evaluation may be overt as in the examples above or covert as in Example 25 which highlights the use of the expression the fact that to describe cases where the fact ascertained by the Court serves as the object of assessment carried out by a dissenting judge and an opportunity to express his or her stance.

(25) The fact that it is based on a statutory enactment and a judicial order entered for her special protection, rather than on a formal contract, does not provide a principled basis for refusing to consider it "property" worthy of constitutional protection [41]. 
Clearly, facts are central to judicial argumentation and reasoning and they are the essence of narrative in judicial opinions [27]. Linguistically-oriented research demonstrates that the phrase the fact that is highly patterned and it performs various discourse functions, one of which is to make epistemic and evaluative judgments regarding legal entities and processes [27, 31].

\section{Conclusions}

This paper is the first attempt to examine the institution of votum separatum or separate opinion from a comparative, cross-language perspective using a linguistic methodology. The point of departure was the observation that expressing judicial dissent in the Polish judicial system in general and before the Constitutional Tribunal in particular, is no longer treated as an irrelevant distraction incompatible with the civil law model of judicial decision-making. Instead, it is becoming increasingly accepted that a court does not speak with one voice. The communicative aspects of separate opinions have come to the fore in light of full accessibility of judicial opinions or judgments afforded by the contemporary media and the Internet technologies. Judicial dissent can now be readily communicated to a range of diverse audiences and this holds true for both the US opinions and Poland's Constitutional Tribunal judgments. The right to voice judicial protest is now regarded as the hallmark of judicial independence and the transparency of the judicial decision-making process. Given this significance, it is surprising to note that separate opinions have never been studied from a corpus linguistic perspective until now. The only previous genre-based study of judicial dissent that has been carried out is qualitative in orientation and it focuses on a single jurisdiction [11]. The present comparative and corpus-based research thus forms a novel and necessary counterpoint to the previous study. Adopting a genre-based perspective, the ensuing analysis shows that legal justifications can be treated as recognizable communicative events. The study has documented a substantial similarity in terms of how separate opinions are fully integrated within the structures of the US SC opinions and the Constitutional Tribunal judgments. Equally revealing is that judges in both cases tend to employ highly formulaic expressions, (such as I enter my dissent against the ruling of the Constitutional Tribunal), to signal their disagreement, despite the absence of clear guidelines that would prescribe precise ways in which their stance should be declared. This is particularly noteworthy in the case of Polish separate opinions, which are still relatively recent in the judicial decision-making process, and yet, they have already developed certain conventionalized forms of expression.

In addition, the analysis of very frequent phraseology shows that declaring votum separatum and their justifications are two different acts, not only legally but also linguistically. The analysis reveals important differences between American and Polish texts regarding frequent phraseology (as evidenced through the lexical bundles analysis). In Polish justifications, it revolves around legal actors, documents and domainspecific terminology. In other words, it is more concerned with the world of law and its attributes. In contrast, the most frequent phraseology in American opinions, not only sheds light on the peculiarities of judicial argumentation but it also points 
towards the presence of strong evaluative concerns. This shows that judges not only openly and routinely express their disagreement with a majority opinion but they also justify it by assessing (negatively) the outcome of the judicial decision-making process and/or its rationale using predictable lexico-grammatical patterning. While far more work is needed to corroborate this finding, it seems that the American justifications could rely, to a greater extent, on recurrent expressions in their argumentative styles. It remains to be seen what linguistic strategies are used by Polish judges, which are likely to be more idiosyncratic and less frequent.

Given the preliminary and exploratory nature of this study and the paucity of comparative research into legal justification, this study has been envisaged as laying the groundwork for further research needed to provide a systematic description of the linguistic construal of what amounts to a highly complex conglomerate of axiological, argumentative, dogmatic and pragmatic aspects. Future research could be extended in many different directions. One possible line of research could address intersubjectivity and positioning in how judges evaluate different arguments and align themselves with different legal actors and entities. For example, while separate opinions are universally discursive and dialogic in that they engage with arguments advanced in majority opinions, Polish judges in their separate opinions do not acknowledge or refer to other separate opinions written in the same case. Finally, given the central role of assessments in justification, future research could look into the role of evaluative language in the counter-arguments advanced by dissenting judges, especially in light of constructive criticism usually expected of them.

Acknowledgements Research reported in this paper was supported by Narodowe Centrum Nauki [National Science Centre Poland] under award number UMO-2018/31/B/HS2/03093.

Open Access This article is licensed under a Creative Commons Attribution 4.0 International License, which permits use, sharing, adaptation, distribution and reproduction in any medium or format, as long as you give appropriate credit to the original author(s) and the source, provide a link to the Creative Commons licence, and indicate if changes were made. The images or other third party material in this article are included in the article's Creative Commons licence, unless indicated otherwise in a credit line to the material. If material is not included in the article's Creative Commons licence and your intended use is not permitted by statutory regulation or exceeds the permitted use, you will need to obtain permission directly from the copyright holder. To view a copy of this licence, visit http://creativecommons.org/licen ses/by/4.0/.

\section{References}

1. Anthony, Laurence. 2014. AntConc. Tokyo: Waseda University. http://www.laurenceanthony.net/. Accessed 20 January 2014.

2. Archer et ux. V Warner, Case No. 01-1418, 31 March 2003. .

3. Ashcroft, Attorney General v American Civil Liberties Union et al., Case No. 00-1293, 13 May 2002.

4. Barnhart, Commissioner of Social Security v Sigmon Coal Co., Inc., et al., Case No. 00-1307, 19 February 2002.

5. BedRoc Limited, LLC, and Western Elite, Inc. v United States, Case No. 02-1593, 31 March 2004.

6. Bhatia, Vijay K. 2004. Worlds of Written Discourse-A Genre-Based View. London: Continuum.

7. Bhatia, Vijay K. 2017. Critical Genre Analysis. Investigating Interdiscursive Performance in Professional Practice. London and New York: Routledge. 
8. Bhatia, Vijay Kuma. 1993. Analysing Genre. Language Use in Professional Settings. Essex: Longman.

9. Biel, Łucja. 2014. Lost in the Eurofog. The Textual Fit of Translated Law. Frankfurt am Main: Peter Lang.

10. Blake, William D., and Hans J. Hacker. 2010. 'The Brooding Spirit of the Law': Supreme Court Justices Reading Dissents from the Bench. The Justice System Journal 31 (1): 1-25.

11. Bowles, Hugo. 2002. How Judges Agree to Disagree: Social and Linguistic Patterns of Dissent in the English Legal Process. In Conflict and Negotiation in Specialised Texts, ed. Maurizio Gotti, Dorothee Heller, and Marina Dossena, 143-164. Bern: Peter Lang.

12. Branch v Smith, Case No. 01-1437, 31 March 2003.

13. Breeze, Ruth. 2013. Lexical Bundles Across Four Legal Genres. International Journal of Corpus Linguistics 18 (2): 229-253. https://doi.org/10.1075/ijcl.18.2.03bre.

14. Brostoff, Teresa, and Ann Sinsheimer. 2003. Legal English: An Introduction to the Legal Language and Culture of the United States, 2nd ed. Dobbs Ferry, NY: Oceana Publications.

15. DiMatteo, Larry. 2015. Legal Justification in Anglo-American Common Law. In Uzasadnienia decyzji stosowania prawa [Justification in Judicial Decision-Making Process], ed. Iwona RzucidłoGrochowska and Mateusz Grochowski, 512-524. Warsaw: Wolters Kluwer.

16. Garlicki, Lech. 2007. Constitutional Courts Versus Supreme Courts. International Journal of Constitutional Law 5 (1): 44-68. https://doi.org/10.1093/icon/mol044.

17. Ginsburg, Ruth Bader. 2010. The Role of Dissenting Opinions. Minnesota Law Review 95 (1):1-8.

18. Goźdź-Roszkowski, Stanisław. 2011. Patterns of Linguistic Variation in American Legal English. A Corpus-Based Study. Frankfurt am Main: Peter Lang.

19. Goźdź-Roszkowski, Stanisław. 2020. Move Analysis of Legal Justifications in Constitutional Tribunal Judgments in Poland: What They Share and What They Do Not. International Journal for the Semiotics of Law. https://doi.org/10.1007/s11196-020-09700-1.

20. Grochowski, Mateusz. 2015. Uzasadnienie zdania odrębnego [The justification of separate opinions]. In Uzasadnienia decyzji stosowania prawa [Justification in Judicial Decision-Making Process], ed. Iwona Rzucidło-Grochowska and Mateusz Grochowski, 38-169. Warsaw: Wolters Kluwer.

21. Hamdan v Rumsfeld, Secretary of Defence, et al., Case No. 05-184, 29 June 2006.

22. Hussain, Ijaz. 1984. Dissenting and Separate Opinions at the World Court. Dordrecht: Martinus Nijhoff Publishers.

23. John Ashcroft, Attorney General, Petitioner v American Civil Liberties Union et al., Case No. 00-1293, 13 May 2002.

24. Kelemen, Katalin. 2013. Dissenting Opinions in Constitutional Courts. German Law Journal 14 (8): 1345-1371.

25. Kelemen, Katalin. 2017. Judicial Dissent in European Constitutional Courts: A Comparative and Legal Perspective. London and New York: Routledge.

26. Kirby, Michael. 2007. Judicial Dissent. Common Law and Civil Law Traditions. Law Quaterly Review 123: 3 .

27. Klinck, Dennis R. 1992. The Word of the Law. Approaches to Legal Discourse. Ottawa: Carleton University Press.

28. Królikowski, Jakub. 2015. Uzasadnienia orzeczeń Trybunału Konstytucyjnego [Justifications of Constitutional Tribunal decisions]. In Uzasadnienia decyzji stosowania prawa [Justification in Judicial Decision-Making Process], ed. Iwona Rzucidło-Grochowska and Mateusz Grochowski, 427439. Warsaw: Wolters Kluwer.

29. Lee, Debra, Charles Hall, and Marsha Hurley. 1999. American Legal English. Using Language in Legal Contexts. Ann Arbor: The University of Michigan Press.

30. Legal Information Institute. n.d. https://www.law.cornell.edu.

31. Macagno, Fabrizio. 2016. Defining Marriage: Classification, Interpretation, and Definitional Disputes. Informal Logic 36 (3): 309-332.

32. Masterpiece Cakeshop, Ltd., et al., Petitioners v. Colorado Civil Rights Commission, et al, Case No. 16-111, 4 Jun 2018.

33. Mazzi, Davide. 2018. 'By partially renouncing their sovereignty...' On the discourse function(s) of lexical bundles in EU-related Irish judicial discourse. In Phraseology in Legal and Institutional Settings A Corpus-based Interdisciplinary Perspective, ed. Stanisław Goźdź-Roszkowski and Gianluca Pontrandolfo, 189-202. London and New York: Routledge.

34. Poland's Constitutional Tribunal. n.d. https://ipo.trybunal.gov.pl/ipo. 
35. Ricky Bell, Warden, Petitioner v Gregory Thompson, Case No. 04-514, 27 June 2005.

36. Schneider, Steffen, Frank Nullmeier, and Achim Hurrelmann. 2007. Exploring the Communicative Dimension of Legitimacy: Text Analytical Approaches. In Legitimacy in an Age of Global Politics. Transformations of the State, ed. Hurrelmann Achim, Steffen Schneider, and Jens Steffek, 126-155. London: Palgrave Macmillan.

37. Skrętowicz, Edward. 1984. Zdanie odrębne w procesie karnym [Separate opinion in criminal proceedings]. Annales UMCS 31: 104-124.

38. Susette Kelo, et al., Petitioners v City of New London, Connecticut, et al, Case No. 04-108, 23 June 2005.

39. Swales, John. 1990. Genre Analysis English in Academic and Research Settings. Cambridge: Cambridge University Press.

40. Tiersma, Peter M. 1999. Legal Language. Chicago: The University of Chicago Press.

41. Town of Castle Rock, Colorado v Gonzales et al., Case No. 04-278, 27 June 2005.

42. US Supreme Court. n.d. www.supremecourt.gov.

43. Vitale, David. 2014. The Value of Dissent in Constitutional Adjudication: A Context-Specific Adjudication. Review of Constitutional Studies 19 (1): 83-108.

44. Zdanie odrębne, Case No. 34/16, 13 December 2018.

45. Zdanie odrębne, Case No. K 9/12, 19 December 2012.

46. Zdanie odrębne, Case No. K 21/14, 28 October 2015.

47. Zdanie odrębne, Case No. K 31/12, 7 November 2013.

48. Zdanie odrębne, Case No. P 27/13, 12 March 2014.

49. Zdanie odrębne, Case No. SK 31/14, 28 June 2016.

Publisher's Note Springer Nature remains neutral with regard to jurisdictional claims in published maps and institutional affiliations. 